\title{
ANALISIS PENGARUH TINGKAT PENDIDIKAN IBU DAN PEMBERIAN ASI EKSKLUSIF TERHADAP KEJADIAN STUNTING PADA BALITA DI PROVINSI KALIMANTAN TENGAH
}

\author{
Analysis Of The Effect Mother's Education Level And Exclusive Breastfeeding On The \\ Event Of Stunting In Children In Province of Central Kalimantan
}

\author{
Rezqi Handayani ${ }^{*}$ \\ Nurul Qamariah ${ }^{2}$ \\ Haris Munandar ${ }^{3}$ \\ 1,2, Program Studi D-III Farmasi, \\ Fakultas Ilmu Kesehatan, \\ Universitas Muhammadiyah \\ Palangkaraya, Kota Palangka \\ Raya, Kalimantan Tengah, \\ Indonesia \\ 3, Program Studi PGSD, \\ Fakultas Keguruan dan Ilmu \\ Pendidikan, Universitas \\ Muhammadiyah Palangkaraya, \\ Kota Palangka Raya, Kalimantan \\ Tengah, Indonesia
}

*email:

rezqihandayani79@gmail.com

Kata Kunci:

Tingkat Pendidikan lbu ASI Eksklusif

Kejadian Stunting pada Balita

ProvinsiKalimantan Tengah

\section{Keywords:}

Mother's Education Level

Exclusive Breastfeeding

Stunting Incidence in Children

Province of Central Kalimantan

\begin{abstract}
Abstrak
Berdasarkan data Studi Status Gizi Balita Indonesia (SSGBI) 2019 prevalensi stunting terendah adalah Murung Raya (17,45\%), Lamandau (17,83\%) dan Kotawaringin Barat (23,98\%). Sedangkan Kabupaten dengan prevalensi tertinggi adalah Kabupaten Kapuas (42,37\%), Kotawaringin Timur (39,87\%) dan Barito Timur (38,53\%). Hasil pemantauan status gizi yang rutin dilaksanakan oleh kabupaten/kota melalui EPPBGM menyatakan bahwa persentase gizi kurang pada balita usia 0-59 bulan di Provinsi Kalimantan Tengah pada tahun 2019 sebesar 10,I persen. Salah satu dampak buruk dari permasalahan gizi adalah stunting. Kasus stunting pada anak balita masih menjadi masalah kesehatan yang perlu diwaspadai di Indonesia. Salah satu faktor penyebab terjadinya stunting adalah tingkat pendidikan ibu serta pemberian Air Susu lbu (ASI) pada bayi dan balita. Penelitian melakukan analisis hubungan tingkat pendidikan ibu dan pembeiaran ASI ekslusif pada balita kejadian stunting di Provinsi Kalimantan Tengah. Penelitian ini menggunakan desain penelitian cross sectional dengan analisis data univariat dan analisis bivariat. Analisis univariat bertujuan untuk mendeskripsikan distribusi balita berdasarkan usia, berdasarkan jenis kelamin, tingkat pendidikan ibu, distribusi pemberian asi ekslusif, dan status gizi balita berdasarkan data profil kesehatan dalam bentuk tabel distribusi frekuensi. Analisis bivariat pada penelitian ini menggunakan uji Chi-square test. Hasil penelitian menunjukkan bahwa ada hubungan yang signfikan atau bermakna antara tingkat Pendidikan ibu dan pemberian ASI ekslusif dengan kejadian stunting pada balita di provinsi Kalimantan tengah tahun 2019.
\end{abstract}

\begin{abstract}
Based on data from the 2019 Indonesian Toddler Nutritional Status Study (SSGBI) the lowest prevalence of stunting was Murung Raya (I7.45\%), Lamandau (I7.83\%) and West Kotawaringin (23.98\%). Meanwhile, the districts with the highest prevalence were Kapuas (42.37\%), East Kotawaringin (39.87\%) and East Barito (38.53\%). The results of routine monitoring of nutritional status carried out by districts/cities through E-PPBGM stated that the percentage of undernourished children aged 0-59 months in Central Kalimantan Province in 2019 was $10.1 \%$. One of the bad effects of nutritional problems is stunting. The case of stunting in children under five is still a health problem that needs to be watched out for in Indonesia. One of the factors causing stunting is the mother's education level and the provision of breast milk (ASI) to infants and toddlers. The study analyzed the relationship between maternal education level and exclusive breastfeeding for children under five with stunting in Central Kalimantan Province. This study used a cross-sectional research design with univariate data analysis and bivariate analysis. The Univariate analysis aims to describe the distribution of children under five by age, by gender, level of mother's education, distribution of exclusive breastfeeding, and nutritional status of children under five based on health profile data in the form of a frequency distribution table. Bivariate analysis in this study used the Chi-square test. The results showed that there was a significant or significant relationship between the level of mother's education and exclusive breastfeeding with the incidence of stunting in children under five in the province of Central Kalimantan in 2019.
\end{abstract}




\section{PENDAHULUAN}

Salah satu goal yang tertuang dalam MDGS adalah Scaling Up Nutrition (SUN) (Kemenko, 20I3). SUN adalah dorongan global tindakan dan investasi untuk meningkatkan gizi ibu dan anak. Berdasarkan yang tertuang pada Pedoman Perencanaan Program Gerakan 1000 Hari Pertama Kehidupan, fakta menunjukkan bahwa nutrisi yang tepat selama 1.000 hari antara awal kehamilan seorang wanita hingga usia anaknya dua tahun memberikan anak-anak yang sehat dalam hidup. Gizi buruk selama periode ini mengarah pada konsekuensi seperti pertumbuhan dan perkembangan kognitif terhambat yang ireversibel.Tujuan Global SUN Movement adalah menurunkan masalah gizi, dengan fokus pada $\mathrm{I} .000$ hari pertama kehidupan (270 hari selama kehamilan dan 730 hari dari kelahiran sampai usia 2 tahun) yaitu pada ibu hamil, ibu menyusui dan anak usia 0-23 bulan. Indikator Global SUN Movement adalah penurunan Bayi Berat Lahir Rendah (BBLR), anak balita pendek (stunting), kurus (wasting), gizi kurang (underweight), dan gizi lebih (overweight) (Proverawati dan Erna, 2010). Gizi merupakan bagian penting dalam pertumbuhan dan perkembangan, karena terdapat keterkaitan dan berhubungan dengan kesehatan dan kecerdasan (Proverawati dan Erna, 20l0).

Salah satu dampak buruk dari permasalahan gizi adalah stunting. Stunting atau balita pendek adalah balita dengan masalah gizi kronik, yang memiliki status gizi berdasarkan panjang atau tinggi badan menurut umur balita jika dibandingkan dengan standar baku WHOMGRS (Multicentre Growth Reference Study) tahun 2005, memiliki nilai z-score kurang dari -2SD dan apabila nilai z-scorenya kurang dari-3SD dikategorikan sebagai balita sangat pendek (Kemenkes, 20I5). Stunting terjadi mulai janin masih dalam kandungan dan baru nampak saat anak berusia dua tahun. Permasalahan Stunting merupakan isu baru yang berdampak buruk terhadap permasalahan gizi di Indonesia karena mempengaruhi fisik dan fungsional dari tubuhanak serta meningkatnya angka kesakitan anak, bahkan kejadian stunting tersebut telah menjadisorotan WHO untuk segera dituntaskan (Kania, 20I5).

Salah satu faktor penyebab terjadinya stunting yang pada WHO (20I3) adalah pemberian ASI pada bayi dan balita. Pemberian ASI merupakan faktor penting bagi petumbuhan dan perkembangan serta kesehatan anak. WHO dan Unicef (2002) dalam Global strategy on infant and young child feeding tahun 2002 merekomendasikan 4 (empat) pola makan terbaik bagi anak sampai usia 2 tahun, yaitu Inisiasi Menyusui Dini (IMD) dalam 30 sampai 60 menit pertama setelah lahir, memberikan ASI eksklusif sampai bayi usia 6 bulan, mulai memberikan makanan pendamping mulai usia 6 bulan dan meneruskan pemberian ASI sampai anak berusia 2 tahun. Perilaku pemberian ASI secara eksklusif sampai 6 bulan ternyatamasih belum maksimal. Data Survei Sosial Ekonomi Nasional (SUSENAS) 2005 dan 2006 prevalensi pemberian ASI eksklusif di Indonesia baru mencapai 18,1\% tahun 2005 dan 21,2\% pada tahun 2006. Sementara hasil Survei Demografi dan kesehatan Indonesia (SDKI) 2007 diperoleh angka pemberian ASI eksklusif sampai 6 bulan hanya 8,1\%. Angka ini sangat jauh dari target cakupan pemberian ASI eksklusif yang ditetapkan pemerintah, yaitu $80 \%$ pada tahun 2010. Prevalensi pemberian ASI eksklusif pada tahun 2019 mengalami kenaikan sebesar $67.74 \%$, dan mengalami penurunan lagi pada tahun 2020 yaitu 66,1\%. Penelitian Ahmad et al. (2010) bahwa stunting lebih banyak ditemukan pada anak yang tidak diberi ASI eksklusif dibandingkan anak yang diberi ASI eksklusif. Terdapat kecenderungan penyakit infeksi seperti diare dan penyakit pernafasan akan lebih mudah mengenai bayi yang diberikan ASI yang kurang dan pemberian makanan atau formula yang terlalu dini dikarenakan ASI sebagai anti infeksi sehingga dapat meningkatkan risiko kejadian stunting (Rahayu, 20I I; Candra et al., 20II). 
Di provinsi Kalimantan Tengah pada tahun 2018 angka prevalensi kekuarangan gizi balita $0-23$ bulan sebesar $18,50 \%$ dan angka prevalensi kekurangan gizi balita 0 59 bulan sebesar $21,80 \%$. Hasil pemantauan status gizi yang rutin dilaksanakan oleh kabupaten/kota melalui EPPBGM menyatakan bahwa persentase gizi kurang pada balita usia 0-59 bulan di Provinsi Kalimantan Tengah pada tahun 2019 sebesar 10,I persen. Hal tersebut berbeda jauh dengan hasil Riset Kesehatan Dasar (Riskesdas) diselenggarakan oleh Kementerian Kesehatan tahun 2018, yaitu persentase gizi kurang sebesar 16,9 persen. Kabupaten dengan persentase tertinggi. gizi kurang pada balita usia 0-59 bulan tahun 2019 adalah Kabupaten Gunung Mas 21,9 persen, Kabupaten Kapuas 2I,2 persen dan Kotawaringin Timur 18,8 persen. Sedangkan Kabupaten dengan persentase terendah adalah Kota Palangka Raya 3 persen, Kabupaten Seruyan 3 persen dan Barito Utara 3,8 persen.

Tingkat pendidikan dapat memudahkan seseorang atau masyarakat untuk menyerap informasi dan menerapkannya dalam perilaku hidup sehari-hari (Astari, 2006). Berdasarkan penelitian Masithah et al.(2005) lama pendidikan ibu berhubungan dengan status gizi balita menurut indeks z-skor TB/U. Perilaku ibu dalam mengasuh balitanya memiliki kaitan yang erat dengan kejadian wasting pada balita. Ibu dengan pola asuh yang baik akan cenderung memiliki anak dengan status gizi yang baik pula, begitu juga sebaliknya, ibu dengan pola asuh gizi yang kurang cenderung memiliki anak dengan status gizi yang kurang pula (Virdani, 2012). Pola asuh ibu merupakan perilaku ibu dalam mengasuh balita mereka. Perilaku sendiri berdasarkan Notoatmodjo (2005) dipengaruhi oleh sikap dan pengetahuan. Oleh karena ini penelitian ini diharapkan dapat melakukan analisis terhadap pengaruh pendidikan ibu terhadap kejadian stunting di Provinsi Kalimantan Tengah. Selain itu pada penelitian ini juga akan dilakukan analisis terhadap pengaruh pemberian Air
Susu Ibu (ASI) terhadap prevalensi stunting di Provinsi Kalimantan Tengah.

\section{METODOLOGI}

Penelitian ini merupakan penelitian observasional dengan desain cross sectional. Studi cross sectional merupakan suatu observasional (non-eksperimental) yang hanya bersifat deskriptif dan juga merupakan studi analitik. Populasi adalah wilayah generalisasi yang merupakan subjek atau objek yang memiliki kuantitas dan karakteristik yang mencerminkan kaidah yang ditetapkan oleh peneliti (Sugiyono, 20II). Populasi pada penelitian ini adalah seluruh balita stunting berdasarkan data Presentase Balita Stunting Kabupaten/Kota di Provinsi Kalimantan Tengah Tahun 2019 sebanyak 3.138. Sampel merupakan bagian dari jumlah dan karakteristik yang dimiliki oleh populasi. Penentuan sampel harus benar-benar representatif (Sugiyono, 20II). Sampel dalam penelitian ini diambil dari total keseluruhan populasi dengan jumlah 3138 jumlah balita diprovinsi Kalimantan Tengah.

Sumber data penelitian ini menggunakan data sekunder yang merupakan sumber data penelitian melalui media perantara. Data sekunder dapat berupa bukti, catatan atau laporan yang telah tersusun dalam data dokumen yang di publikasikan (Ali, 20I2). Data sekunder pada penelitian ini adalah data profil Dinas Kesehatan Provinsi Kalimantan tengah tahun 2019 Kementrian Kesehatan Republik Indonesia. Analisis data menggunakan analisis univariat dan analisis bivariat. Analisis univariat bertujuan untuk mendeskripsikan distribusi balita berdasarkan usia, berdasarkan jenis kelamin, tingkat pendidikan ibu, distribusi pemberian asi ekslusif, dan status gizi balita berdasarkan data profil kesehatan dalam bentuk tabel distribusi frekuensi. Analisis bivariat pada penelitian ini menggunakan uji Chi-square test. Chi-square ini digunakan untuk mencari korelasi atau hubungan antara variabel tingkat pendidikan ibu dan pemberian 
ASI eksklusif terhadap kejadian stunting pada balita menggunakan aplikasi SPSS v24 for Windows.

\section{HASIL DAN PEMBAHASAN}

Data SSGBI tahun 2019 menunjukkan bahwa 32\% balita di Kalimantan Tengah dinyatakan stunting. Angka yang relative tinggi jika dibandingkan dengan target Millenium Development Goals (MDGs) yaitu I5\%. Jika dilihat berdasarkan data Laporan Kemenkes RI tentang Studi Status Gizi Balita di Indonesia (SSGBI) tahun 2019, semua kabupaten diProvinsi Kalimantan Tengah belum dapat memneuhi target prevalensi yang telah ditagetkan yaitu sebesar $15 \%$.

Tabel I. Analisis Chi-Square Pengaruh Pendidikan ibu terhadap kejadian stunting. di Provinsi Kalimantan Tengah Tahun 2019.

\begin{tabular}{|c|c|c|c|c|c|c|c|c|}
\hline \multirow{3}{*}{$\begin{array}{l}\text { Pendidkan Ibu*Status } \\
\text { Gizi }\end{array}$} & \multicolumn{4}{|c|}{ Pendidikan Ibu } & \multirow{2}{*}{\multicolumn{2}{|c|}{ Jumlah }} & \multirow{3}{*}{$\begin{array}{l}\text { Continuinty } \\
\text { Correction }\end{array}$} & \multirow{3}{*}{$p$ Value } \\
\hline & \multicolumn{2}{|c|}{ Baik } & \multicolumn{2}{|c|}{ Kurang } & & & & \\
\hline & $\mathrm{n}$ & $\%$ & $\mathrm{n}$ & $\%$ & $\mathrm{n}$ & $\%$ & & \\
\hline Normal & 0 & 0 & 2134 & 68 & 2134 & 68 & 3060.452 & 0.000 \\
\hline Stunting & 988 & 31,8 & 16 & 0,2 & 1004 & 32 & & \\
\hline Jumlah & 998 & 31,8 & 2150 & 68,2 & 3138 & 100 & & \\
\hline
\end{tabular}

Berdasarkan tabel I menujukkan bahwa hasil analisis statistik dengan menggunakan chi-squre ini diketahui bahwa ada pengaruh atau hubungan yang bermakna antara Pendidikan ibu dengan kejadian stunting pada balita di Provinsi Kalimantan Tengah tahun 2019. Pada penelitian ini menunjukkan bahwa dari 2150 balita dengan ibu berpendidikan kurang memiliki Z-Skor sebesar 0,2\%. Sedangkan dari 998 balita dengan ibu berpendidikan baik memiliki Z-Skor sebesar $0 \%$. Berdasarkan hasil analisis chi-square dengan tabel $2 \times 2$ diproleh nilaikorelasi (continuity correction) sebesar 3060,452 dengan taraf signifikansi $(P)$ sebesar 0,000 $(p<0,05)$ yang berarti ada hubungan yang signfikan atau bermakna antara tingkat Pendidikan dengan kejadian stunting pada balita di provinsi Kalimantan tengah tahun 2019.

Beberapa faktor yang mempengaruhi hal tesrebut adalah tingkat pendidikan ibu dan pemberian air susu ibu secara eksklusif. Berdasarkan data yang termuat pada profil perempuan di provinsi Kalimantan Tengah tahun 2019, diketahui bahwa tingkap pendidikan perempuan di Provinsi Kalimantan Tengah berada pada level kurang baik sebanyak $68,54 \%$. Hal ini tentu akan berdampak pada tingkat pengetahun perempuan daalm mencegah kejadian stunting pada anak serta akan berdambak pada pengetahuan perempuan terhadap pemberian ASI ekslusif. Latar belakang pendidikan orang tua, baik ayah maupun ibu, merupakan salah satuunsur penting dalam menentukan status gizi anak. Pendidikan ibu disamping merupakan modal utama dalam menunjang perekonomian rumah tangga, juga berperan dalam pola pemberian makan keluarga maupun pola pengasuhan anak (Singarimbun, dalam Handarsari et al, 2010). Berdasarkan penelitian yang dilakukan oleh Mustamin et al (2018) dengan menggunakan data sekunder pada Laporan Status Gizi tahun 2015 di Provoinsi Sulawesi Selatan menunjukkan bahwa tingkat pendidikan ibu memiliki hubungan yang signifikan dengan kejadian stunting pada balita. Pada penelitian ini menunjukkan bahwa dari 507 balita dengan ibu berpendidikan kurang memiliki indeks ZSkor $\mathrm{PB}(\mathrm{TB}) / \mathrm{U}$ stunting (27,7\%), sedangkan dari 39I balita dengan ibu berpendidikan baik sebagian besarmemiliki indeks Z-Skor PB(TB)/U normal (27,3\%). Berdasarkan hasil analisis menghasilkan $\mathrm{p}<0,05$ dengan nilai signifikansi 0,00 I 
yang berarti signifikan atau bermakna. Hasil tersebut sependapat dengan naskah publikasi oleh Rohmatun (2014) yang mengatakan bahwa ada hubungan antara tingkat pendidikan ibu dengan kejadian stunting pada balita di Desa Sidowarno Kecamatan Wonosari Kabupaten Klaten dengan nilai signifikansi 0,007. Tingginya tingkat pendidikan yang dimiliki maka akan mempengaruhi pengetahuan tentang gizi, Pengetahuan ibu tentang gizi berpengaruh pada perilaku ibu dalam menyediakan makanan bagi anaknnya. lbu yang memiliki pengetahuan gizi baik diharapkan mampu menyediakan makanan dengan jenis dan jumlah yang tepat agar anak dapat tumbuh dan berkembang secara optimal (Astari, 2008).

Pola asuh ibu merupakan perilaku ibu dalam mengasuh balita mereka. Perilaku sendiri berdasarkan Notoatmodjo (2005) dipengaruhi oleh sikap dan pengetahuan. Pengetahuan yang baik akan menciptakan sikap yang baik, yang selanjutnya apabila sikap tersebut dinilai sesuai, maka akan muncul perilaku yang baik pula. Pengetahuan sendiri didapatkan dari informasi baik yang didapatkan dari pendidikan formal maupun dari media (non formal), seperti radio, TV, internet, koran, majalah. Tingkat pendidikan memengaruhi seseorang dalam menerima informasi. Orang dengan tingkat pendidikan yang lebih baik akan lebih mudah dalam menerima informasi daripada orang dengan tingkat pendidikan yang kurang. Informasi tersebut dijadikan sebagai bekal ibu untuk mengasuh balitanya dalam kehidupan sehari- hari. Pendidikan ibu merupakan hal dasar bagi tercapainya gizi balita yang baik. Tingkat pendidikan ibu tersebut terkait dengan kemudahan ibu dalam menerima informasi tentanggizi dan kesehatan dari luar. Ibu dengan tingkat pendidikan yang lebih tinggi akan lebih mudah menerima informasi dari luar, dibandingkan dengan ibu yang memiliki tingkat pendidikan lebih rendah. Tingkat pendidikan pada keluarga miskin sebagian besar dalam kategori rendah, hal ini dikarenakan keterbatasan ekonomi yang dialami sehingga mereka tidak mampu melanjutkan pendidikan pada jenjang yang lebih tinggi. Ibu memiliki peranan penting dalam pengasuh anak mulai dari pembelian hingga penyajian makanan. Apabila pendidikan dan pengetahuan ibu tentang gizi rendah akibatnya ia tidak mampu untuk memilih hingga menyajikan makanan untuk keluarga yang memenuhi syarat gizi seimbang (Soekirman, 2000). Ibu rumah tangga berperan dalam pengambilan keputusan konsumsi pangan. Penyajian bahan makanan untuk seluruh anggota rumah tangga menjadi tugas pokok ibu rumah tangga. Oleh karena itu, semakin tinggi tingkat pendidikan ibu rumah tangga maka akan semakin tinggi pula kemampuan dalam hal pengambilan keputusan konsumsi rumah tangga terutama untuk memenuhi kebutuhan gizi seluruh anggota keluarga (Aridal, 20I5).

Menurut Dekkar (2010) dalam Rahayu A dan Khairiyati L (2014) menyatakan bahwa konsumsi makanan bagi setiap orang terutama anak usia I-2 tahun harus selalu memenuhi kebutuhan. Konsumsi makanan yang kurang akan menyebabkan ketidakseimbangan proses metabolisme di dalam tubuh. Apabila hal ini terjadi terus menerus akan terjadi gangguan pertumbuhan dan perkembangan seperti stunting (Rahayu A, dan Khairiyati L, 20I4). Sehingga tingkat pengetahuan ibu merupakan salah satu komponen yang tidak bisa diabaikan. Berdasarkan data Laporan Kemenkes RI tentang Studi Status Gizi Balita di Indonesia (SSGBI) tahun 2019, diketahui bahwa $48,60 \%$ balita di Provinsi Kalimantan Tengah tidak mendapatkan ASI ekslusif. Hal ini tentu memiliki pengaruh pada prevalansi stunting di Provinsi Kalimantan Tengah.

Tabel 2. Analisis Chi-Square Pengaruh Status Pemberian Asi Ekslusif terhadap kejadian stunting. di Provinsi Kalimantan Tengah tahun 2019. 


\begin{tabular}{|c|c|c|c|c|c|c|c|c|}
\hline \multirow{3}{*}{$\begin{array}{l}\text { Pemberian Asi } \\
\text { Ekslusif *Status Gizi }\end{array}$} & \multicolumn{4}{|c|}{ Pemberian Asi Ekslusif } & \multirow{2}{*}{\multicolumn{2}{|c|}{ Jumlah }} & \multirow{3}{*}{$\begin{array}{l}\text { Continuinty } \\
\text { Correction }\end{array}$} & \multirow{3}{*}{$p$ Value } \\
\hline & \multicolumn{2}{|c|}{$\mathrm{Ya}$} & \multicolumn{2}{|c|}{ Tidak } & & & & \\
\hline & $n$ & $\%$ & $\mathrm{n}$ & $\%$ & $\mathrm{n}$ & $\%$ & & \\
\hline Normal & 1613 & $5 I, 4$ & 521 & 16,6 & 2134 & 68 & 1558.529 & 0.000 \\
\hline Stunting & 0 & 0 & 1004 & 32 & 1004 & 32 & & \\
\hline Jumlah & 1613 & $5 I, 4$ & 1525 & 48,6 & 3138 & 100 & & \\
\hline
\end{tabular}

Berdasarkan table 2 menujukkan bahwa hasil analisis statistik dengan menggunakan chi-squre ini diketahui bahwa ada pengaruh atau hubungan yang bermakna antara status pemberian asi ekslusif dengan kejadian stunting pada balita di Provinsi Kalimantan Tengah tahun 2019. Pada penelitian ini menujukkan bahwa dari 1613 balita yang mendapatkan asi ekslusif Sebagian besar memiliki Z-Skor sebesar $5 \mathrm{I}, 4 \%$ sedangkan dari 1525 balita yang tidak mendapatkan asi ekslusif memiliki Z-Skor sebesar 32\%. Berdasarkan hasil analisis chi-square dengan tabel $2 \times 2$ diproleh nilai korelasi (continuity correction) sebesar 1558,529 dengan taraf signifikansi $(p)$ sebesar 0,000 $(p<0,05)$ yang berarti ada hubungan yang signfikan atau bermakna antara status pemberian asi ekslusif dengan kejadian stunting pada balita di provinsi Kalimantan tengah tahun 2019.

Organisasi Kesehatan Dunia dan UNICEF merekomendasikan tentang menyusui adalah sebagai berikut: inisiasi menyusui dalam satu jam pertama setelah melahirkan; ASI eksklusif selama enam bulan pertama; dan dilanjutkan dengan menyusui selama dua tahun atau lebih, dengan tepat, bergizi cukup, umur yang sesuai, makanan pendamping ASI responsif dimulai pada bulan keenam. Hasil penelitian yang dilakukan oleh Mustamin et al (2018) bahwa dari 85I balita yang mendapatkan ASI eksklusif sebagian besar memiliki indeks Z-skor $\mathrm{PB}(\mathrm{TB}) / \mathrm{U}$ normal (5I,7\%) sedangkan dari 47 balita yang tidak mendapatkan ASI eksklusif memiliki indeks $\mathrm{PB}(\mathrm{TB}) / \mathrm{U}$ stunting $(0,9 \%)$. Berdasarkan hasil analisis menghasilkan $\mathrm{P}<0,05$ dengan nilai signifikansi 0,000 yang berarti signifikan atau bermakna. Hal ini berarti ada hubungan yang bermakna antara pemberian ASI eksklusif dengan kejadian stunting pada balita di Provinsi Sulawesi Selatan Tahun 2015 berdasarkananalisis data sekunder Laporan Pemantauan Status Gizi (PSG) tahun 2015. Menurut Prasetyono (2009) ASI mengandung lebih banyak kalsium yang lebih efiesien diserap oleh tubuh dibandingkan kalsium dari susu pengganti lainnya, sehingga dapat memaksimalkan pertumbuhan terutama tinggi badan sehingga dapat menurunkan risiko I yang dapat terjadi kepada balita.

Sesuai dengan rekomendasi IDAI yang dijabarkan oleh Hegar (2013) kolostrum pada ASI sangat kaya akan protein, laktosa pada ASI merupakan sumber karbohidrat yang dapat diserap lebih baik dibandingkan yang ada pada susu formula, komposisi protein yang lebih banyak sehingga lebih mudah untuk diserap usus bayi, asam amino dan nukleotida yang berperan dalam perkembangan jaringan otak, saraf, kematangan usus, penyerapan besi, dan daya tahan tubuh yang lebih besar dibandingkan susu formula. Selain itu, lemakpada ASI yang memilik profil berbeda dan berjumlah lebih banyak dibanding lemak dalam susu formula. Lemak tersebut berfungsi sebagai pertumbuhan jaringan saraf dan retina mata dan yang tidak kalah penting adalah ASI juga kaya akan vitamin dan mineral untuk pertumbuhan sel dan jaringan yang sangat dibutuhkan padamasapertumbuhan. Menurut penelitian oleh Prasetyono (2009) Bayi yang diberikan ASI Eksklusif memiliki daya tahantubuh yang lebih baik dibandingkan dengan bayi yang tidak diberikan ASI Eksklusif, sehingga membuat anak tidak mudah untuk terserang 
penyakit. ASI mengandung zat gizi yang sangat dibutuhkan oleh bayi seperti karbohidrat, protein, lemak, garam dan mineral, antibodi dan immunoglobulin yang mengakibatkan bayi tidak mudah untuk terserang penyakit dan infeksi seperti diare.

ASI kaya dengan berbagai faktor aktif khususnya antibodi atau immunoglobulin, ASI mengandung immunoglobulin $M, A, D, G$, dan $E$ namun yang paling banyak ialah slgA. Sekretori IgA pada ASI merupakan sumber utama imunitas, ia berperan sebagai faktor protektif penting terhadap infeksi (Aldy et al. , 2016). Antibody yang terkandung didalam ASI memberikan efek penting terhadap system kekebalan tubuh pada bayi sehingga bayi memiliki system imunitas yang baik dan memiliki risiko yang rendah untuk mengalami penyakit infeksi, hal tersebut dapat mendukung proses pertumbuhan dan perkembangan serta dapat mengurangi faktor risiko untuk mengalami kejadian stunting.

ASI dan susu formula pada kenyataannya memang dapat memenuhi gizi anak, tetapi susu formula tidak memiliki antibodi dan immunoglobin yangdimiliki oleh ASI, hal tersebut menyebabkan anak akan rentan untuk terserang penyakit (Lestari et al., 2018) Selain itu kandungan zat gizi lainnya yang terdapat didalam ASI seperti kalsium, fosfor, natrium dan kalium yang lebih rendah dari susu formula dan kandungan kobalt, tembaga, dan selenium yang lebih tinggi tersebut telah sesuai dengan kebutuhan bayi sehingga dapat memaksimalkan penyerapan nutrisi sehingga dapat memaksimalkan pertumbuhan termasuk tinggi badan sehingga bayi memiliki risiko yang lebih rendah untuk mengalami stunting (Prasetyono, 2009). Menurut Sulistyaningsih dan Sari (2018), pola menyusu yang berhubungan dengan kejadian stunting salah satunya adalah tidak melakukan IMD (inisiasi menyusu dini) dan mengatakan bahwa IMD merupakan salah satu faktor risiko terjadinya stunting dengan hasil yang diperoleh OR = 3,04 (2,7I-3,40). Sejalan dengan penelitian tersebut studi yang dilakukan oleh
Muldiasman et al., (2018) menyatakan bahwa anakanak yang tidak mendapatkan inisiasi menyusui dini memiliki kemungkinan risiko I,3 kali lebih besar untuk mengalami stunting. Inisiasi menyusui dini pada balita adalah suatu hal yang sangat mudah dilakukan oleh seorang ibu dan hal tersebut sangat bermanfaat terhadap Kesehatan jangka Panjang bagi anak.

Selain itu, pentingnya dukungan keluarga dan lingkungan sangat mempengaruhi ibu untuk memberikan ASI eksklusif kepada bayi. Menurut penelitian Prasetyowati et al (2010) dukungan petugas kesehatan dan dukungan keluarga berpengaruh terhadap pemberian ASI eksklusif pada bayi usia 6-12 bulan dengan hasil berurutan $\mathrm{p}$ value $=0,027$ dan $\mathrm{P}$ value $=0,017 \quad(p<0,05)$. Dukungan lingkungan dan keluarga sejatinya sangatpenting bagi kondisi ibu untuk mendukung psikologis ibu agar dapat memberikan nutrisi yangtepatkepada bayinya. Menurut penelitian Sari et al( 2017) agar proses laktasi ibu lancar perlu adanya dukungan dari ibu menyusui tersebut terutama kondisi kesehatan fisik dan mental ibu karena kondisi kesehatan ibu tersebut sangat berpengaruh terhadap kelancaran produksi ASI, selain itu hasil penelitian menunjukkan bahwa teknik menyusui,frekuensi, durasi dan gizi ibu mendapatkan hasil yang signifikan dan menunjukkan hubungan yang positif terhadap pertumbuhan bayi. Sejalan dengan penelitian di Pakistan yang dilakukan oleh Syeda et al (2020) mengatakan bahwa durasi menyusui memiliki hubungan yang signifikan dengan stunting pada anakanak di tahun kedua menyusui dan anak-anak yang menyusui ditahun ketiga kehidupannya memiliki peluang lebih tinggi untuk mengalami kejadian stunting yang lebih parah.

\section{KESIMPULAN}

Kesimpulan yang diperoleh dari penelitian ini adalah :

I. Tingkat pendidikan perempuan merupakan salah satu faktof yang mempengaruhi kejadian stunting, 
dan tingkat pendidikan perempuan di Provinsi Kalimantan Tengah berada pada level “Kurang”, serta hasil analisis menunjukkan terdapat hubungan signifikasi antara tingkat pendidikan perempuan terhadap kejadian stunting di Kalimantan Tengah

2. Pemberian ASI ekslusif pada balita di provinsi Kalimantan Tengah merupakan salah satu faktor yang mempengaruhi kejadian stunting, hal ini ditunjukan terdapatnya signifikasi antara pemberian ASI ekslusif terhadap kejadian stunting di Kalimantan Tengah

\section{UCAPAN TERIMAKASIH}

Penelitian ini merupakan hasil dari kerjasama Penelitian Bidang Pembangunan Keluarga, kependudukan, dan Keluarga berencana, oleah karena itu penulis mengycapkan terimakasih kepada atas dukungan yang diberikan oleh kepada Badan Kependudukan dan Keluara Berencana Provisin Kalimantan Tengah.

\section{REFERENSI}

I. Kemenko Kesejahteraan Rakyat (2013). Pedoman Perencanaan Program Gerakan 1000 Hari Pertama Kehidupan. Jakarata

2. Diva Press Prasetyo, Proverawati, Atikah., \& Kusuma W. E. (20I0). Ilmu Gizi Untuk Keperawatan dan Gizi Kesehatan. Nuha Medika. Yogyakarta

3. Kementrian Kesehatan RI. (20I5). Rencana Strategis Kementerian Kesehatan Tahun 20152019. Jakarta

4. Kania, D. (20I5). Indonesia Peringkat Lima Besar Anak Penderita Stunting. https://lifestyle.okezone.com/read/2015/01/23/48 I/1096366/indonesiaperingkatlima-besar-anakpenderita-stunting

5. UNICEF. (2007). Progress For Children: A World Fit for Children. New York: UNICEF Division of Communication

6. Ahmad, Aripin, Suryana, Yulia F. (2010). ASI Eksklusif Anemia dan Stunting pada Anak Baduta
(6-24 bulan) Di Kecamatan Darul Imarah Kabupaten Aceh Besar. Jurnal Gizi Poltekkes Kemenkes Aceh: Aceh

7. Rahayu, A., \& LailyiK. (20|4). Resiko Pendidikan Ibu Terhadap Kejadian Stunting Pada Anak 6-23 Bulan ( Material Education As Risk Factor Stunting Of Child 6-23 Months-Old). Panel Gizi Makan,37(2): I29-I36.

8. Candra A. (2010). Hubungan Underlying Factors Dengan Kejadian Stunting Pada Anak Usia I - 2 Tahun. UNDIP

9. Kementerian Kesehatan RI. (2010). Riset Kesehatan Dasar (RISKESDAS) Tahun 2010. Jakarta

10. Astari. (2006). Faktor-Faktor Yang Berpengaruh Terhadap Kejadian Stunting Pada Anak Usia 6-12 Bulan Di Kabupaten Bogor. Pascasarjana Institut Pertanian Bogor

II. Masitoh, dkk. (2005). Strategi Pembelajaran TK. Jakarta: Universitas Terbuka

12. Notoatmodjo, S. (2005). Promosi Kesehatan Teori dan Aplikasi. Jakarta: Rineka Cipta Prasetyono, D. (2009). Buku Pintar ASI Eksklusif. Yogyakarta:

13. Mustamin, Ramlan Asbar, Budiawan. (20/8). Tingkat Pendidikan Ibu Dan Pemberian Asi Eksklusif Dengan Kejadian Stunting Pada Balita Di Provinsi Sulawesi Selatan. Media Gizi Pangan, Vol. 25, Edisi I, 2018

14. Rohmatun, N. Y. (20|4). Hubungan Tingkat Pendidikan Ibu Dan Pemberian ASI Eksklusif Dengan Kejadian Stunting Pada Balita Di Desa Sidowarno Kecamatan Wonosari Kabupaten Klaten. Naskah Publikasi Program Studi Gizi Fakultas Ilmu Kesehatan Universitas Muhammadiyah Surakarta

15. Aldy, O. S. Lubis, B. M, Sianturi, P. Azlin, E. Tjipto, G. D (2016) 'DampakProteksi Air Susu IbuTerhadap Infeksi',SariPediatri, I I(3),p. I67.doi: |0.| |4238/sp | |.3.2009.|67-73.

16. Arida. (2015). Analisis Ketahanan Pangan Rumah Tangga Berdasarkan Proporsi Pengeluaran Pangan Dan Konsumsi Energi. Skripsi

17. Kementerian Kesehatan R.I. 20I3. Riset Kesehatan Dasar (RISKESDAS) 2013. Jakarta: Badan Penelitian dan Pengembangan Kesehatan. Jakarta. 
18. Lestari, E. F. and Dwihestie, L. K. (2020) 'ASI Eksklusif Berhubungan dengan Kejadian Stunting pada Balita', Jurnal IImiah Permas: Jurnal IImiah STIKES Kendal, I0(2),pp. I29-I36.

19. Sulistianingsih, A. and Sari, R. (2018) ASI eksklusif dan berat lahir berpengaruh terhadap stunting pada balita 2-5 tahun di Kabupaten Pesawaran', Jurnal Gizi Klinik Indonesia, I5(2),p.45.doi: I0.22 |46/ijcn.39086.

20. Sari, D. K., Tamtomo, D. G. and Anantayu, S. (2017) 'Hubungan Teknik, Frekuensi , Durasi Menyusui dan Asupan Energi dengan Berat Badan Bayi Usia I-6 Bulan di Puskesmas Tasikmadu Kabupaten Karanganyar Relations Techniques , Frequency, Duration of Breastfeeding and Energy Intake With Weight Babies in Age I-', PP. I-I3. doi:I0.20473/amnt.vl.il.2017.1-13.Stunting Among Children 0-59 Months Old In Indonesia: Implications of Rising Food Prices. The Journal of Nutrition: 195-200.

2I. Sudiman, H. (2008). Stunting atau Pendek: Awal Perubahan Patologis Atau Adaptasi Karena Perubahan Sosial Ekonomi yang Berkepanjangan. Media Litbang Kesehatan. XVII(I) : 33 - 42.

22. Taguri, A. E. (2008). Risk Factor for Stunting Among Under Fives in Libya. Public Health Nutrition: 12 (8). I|4|-I | 49.

23. Tando, N, M. (20I2). Durasi Dan Frekuensi Sakit balita Dengan Terjadinya Stunting Pada Anak SD Di Kecamatan Malalayang Kota Manado. Naskah Publikasi. GIZIDO. 4(I). 